\title{
Literature in EFL: Beyond language learning
}

\author{
Literatura en inglés como idioma extranjero: \\ más allá del aprendizaje del lenguaje
}

\author{
Luis Jesús Rincón Ussa \\ Universidad de La Salle \\ luisjrincon@gmail.com
}

Received: 31-Oct-2012/Accepted: 27-May-2013

\begin{abstract}
This article presents the results of a qualitative research which looks into the field of literature in EFL. Seventh grade students of a private school in Bogota took part in the research. Data was collected by means of audio recordings of small group discussions, teacher's journal, and responses to literature logs. The results show that the connections that EFL learners make with literary texts enrich their interpretations, analysis and value judgments of experiences and real life events. Furthermore, critical thinking skills are potentiated. In addition to this, literary texts bring up appealing and meaningful topics in the classroom enhancing students' motivation and willingness to use the target language.

Key words: Literature in EFL, life experiences, sociocultural environment, literature and critical thinking in EFL.

\section{Resumen}

Este artículo de investigación presenta los resultados de una investigación cualitativa la cual examinó el valor de la literatura en EFL. La investigación se realizó con estudiantes de séptimo grado en un colegio privado en la ciudad de Bogotá. La recolección de información se realizó por medio de la grabación de discusiones grupales, diario del profesor y producciones escritas de los estudiantes. El análisis de la información evidenció que los estudiantes relacionan los textos literarios con sus experiencias de vida, eventos de la vida real, y elementos propios de su entorno sociocultural. Estas relaciones y conexiones enriquecen las interpretaciones y análisis de las experiencias de vida de los estudiantes así como también de los acontecimientos de la vida real. Los resultados también evidenciaron que la motivación e interés de los estudiantes para comunicar sus ideas en la lengua extranjera se incrementan gracias a que los temas que la literatura provee son relevantes y significativos.

Palabras clave: literatura en EFL, experiencias de vida, entorno sociocultural, literatura y pensamiento crítico en EFL.

\section{Résumé}

Cet articule présente les résultats d'une recherche qualitative qui a examiné la valeur de la littérature dans l'apprentissage de la langue Étrangère (EFL). La recherche s'est effectuée avec un groupe d'étudiants de deuxième année du secondaire d'un collège privé a Bogotá. Le recueil de données s'est fait à partir d'enregistrements de discussions de groups d'étudiants, du journal du chercher et des productions écrites des étudiants. L'analyse de l'information recueillie a mis en évidence que les étudiants mettent en relation les tests littéraires avec leur vécu, des événements de vie réelle, et des éléments propres de leur entourage socio-culturel. Ces relations, ces liens enrichissent les interprétations et les analyses du vécu des étudiants ainsi que les éléments de la vie réelle. Les résultats ont montré également que la motivation et l'intérêt des étudiants pour communiquer en L.E. augmentent grâce à l'importance et la proximité que les sujets véhiculés par la littérature revêtent pour eux.

Mots clés: Littérature en A.L.E, vécu /expériences de vie, entourage, socio-culturel, littérature et pensé critique en EFL.
\end{abstract}




\section{Introduction}

Over the last years many educational changes and adjustments at national, local and institutional level have been taking place. Policies, curriculums, syllabus, programs, and methodologies are continuously being revised and adjusted in order to meet national and global educational needs and trends. Educational intuitions, teachers and students strive to cope with socio-cultural dynamics, educational trends and changes.

In the field of language learning and teaching, numerous methodologies, methods, resources, and techniques are being constantly implemented all around. Right in the center of this dynamic, ever changing and uncertain scenery is the EFL classroom and its inhabitants; the teacher and students. This particular scenario is supposed to educate citizens equipped with competences and skills required to communicate and interact with the rest of the world in a second language.

This article presents the results of a study of one of those particular scenarios in the hope of contributing to understand and consolidate teaching and learning practices in the field of EFL. Two main purposes drove the study; on the one hand, to analyze students' connections to literary texts as well as their reactions and responses before, while and after reading three literary selections. On the other hand, was seen as important to examine the value of literature in EFL in the light of students' free responses and reactions.

The theoretical constructs that frame the research have to do with literature in language learning and the role of the reader in the reading process. Regarding this aspect, Rosenblatt (1991) puts forward the notion of transaction. Rosenblatt affirms that readers are active subjects whose ideas, feelings, emotions, and thoughts play a very important role during the reading process. This research was designed and carried out bearing in mind the active role of EFL learners in the reading process.
Another fundamental element that was taken into account in this research is that language learning processes have to be meaningful; implying that the learning experiences have to be closely related to learners' subjectivity and socio-cultural reality, so that they are able to make concrete connections. In this sense, Lazar (2008) affirms that literature enables learners to understand human feelings, emotions, as well as social problems and conflicts.

On the subject of EFL language learning methodology, the study embraced a communicative stance. This implied that students were encouraged to use the target language to communicate and convey meaning rather than grammatical accuracy.

The results of the data analysis show that literary texts facilitate EFL learners to enrich interpretations, analysis and make more informed value judgments of experiences and real life events. In addition to this, the use of the target language in in-class activities increased.

\section{Literature review}

The principles of reader response theory underpinned and oriented the different stages of the research. Although literary historians suggest that reader-response theory emerged in the 1960s and the 1970s, particularly in America and Germany, for Womack and Davis (2002) the roots of the principles of reader response theory can be traced back as far as the ancient Greek and Roman cultures. According to the authors for these cultures literature was a rhetorical device that was used in order to influence a given audience's reactions. They explain that the ancients understood that the rhetorical strategies in literary works were the means for registering the impact of texts upon their audience.

Nonetheless, the concrete theoretical principles of Reader-response theory can be found in the work of Richards (1929), and Rosenblatt (1930). Richards (1929)identifies the ways in which readers examine the authenticity of a literary work through the narrative's 
effect on their own emotions and experiences. Richards' work shed light on understanding literary interpretation from an individual psychological perspective. According to Womack and Davis (2002) Richards' work underscores the central role of the reader in the reading process as well as in the construction of meaning. These elements were the foundations for Rosenblatt's postulation of "transactional reading" which she developed between 1938 and 1978.

For Rosenblatt, reading is a synergistic relationship between a human being and a text; in which the whole person's subjectivity is involved. The act of reading for Rosenblatt is always a particular event, involving a particular reader, a particular time, and particular circumstances. This author contends that the reader might assume either an "efferent or an aesthetic" stance during the reading process. These stances are part of the continuum while reading. In the efferent stance, the reader's attention is focused on what is literally stated in the text, which Rosenblatt calls the "public meaning". To this stance belong actions like, following directions and instructions, the retaining of information, applying analytic concepts, among others. Here, the readers' feelings, emotions and subjectivity are ignored or subordinated.

Conversely, in the aesthetic stance, the reader focuses on what is being experienced and lived through the reading. Attention is open to a great variety of images, associations, language rhythm and sound, what the text evokes, and in general any feeling, emotion that might arise within the reader. Rosenblatt (1978) describes the act of reading as a 'transaction' that derives from the particular subjectivity and life experiences that define the reader. "Each reader brings to the transaction not only a specific past life and literary history, not only a repertory of internalized 'codes', but also a very active present, with all its preoccupations, anxieties, questions, and aspirations.

(Rosenblatt, 1930, p. 144)

Rosenblatt's transactional reading formulation provides reader-response theory with an interpretational matrix that allows critics to explain readers' motives and their transactions with literary texts.

Booth (1961) makes another significant contribution to the evolution of reader-response theory. He identifies the roles of implied authors and readers in the reading process, as well as the ideological and ethical ramifications of the reading experience. According to Booth, the implied author functions as the actual authors' second self, the kind of person that the reading process constructs, or reconstitutes during the act of reading. For Booth the implied author is responsible for the text's ultimate verbal meanings, as well as for the value systems that contain those meanings. Booth (1961) explains that:

The author creates, in short, an image of himself and another image of his reader. He makes his reader, as he makes his second self, and the most successful reading is one in which the created selves, author and reader, can find complete agreement. (p. 138)

According to Booth, an enjoyable successful reading experience involves two principal factors: the correct identification of the implied reader's belief systems and the implied author's simultaneous attempt to seek agreement with that reader's values. Booth gives considerable attention to the ethical relationship that exists between the text and its audience. He examines the interconnections between our lives and the literary texts. These ideas are connected with Rosenblatt's arguments in the sense that both authors give considerable importance to the reader's active role of his subjectivity during the reading process and the interpretation of a literary text.

Another author who talks about the conceptual roots of reader-response is Tompkins. According to Tompkins (1980) reader-response criticism finds its 
theoretical origins within the boundaries of formalism and New Criticism. The first focuses exclusively on the text as such, without taking into account external elements like audience, history or biography. The latter assumes that a literary text could be studied apart from the reader's psychology and the author's intention. In this sense, Gibson (1950) supports Tompkins's assertion. He studied the relation between the authorial production of texts and their readers. His studies led him to devise the "mock reader" formulation. This formulation allowed him to contend that the rhetorical devices and the language of a literary text invite the reader to assume a particular kind of person. For him the "mock reader" functions like a mask that the reader wears as he explores the mock possibilities available in the narrative. For Gibson the day-to-day life experiences, feelings, and emotions control, simplify and determine the mock reader artifact. He asserts that the relationship between the reader and the author allows the reader to recognize the interconnections between the authorial voices in the text and the manifestations and relations of the reader in the text.

Gibson's work clearly acknowledges the role of the reader in the construction of meaning during the reading process marking a paradigm shift from formalism to New Criticism. In the formalist paradigm the reader is viewed as a passive agent who extracts meaning from the text and analysis its structure. On the other hand, New-criticism explores what happens during the reading process, and views the reader as an active dynamic agent whose subjectivity and life experiences have an important role in the interpretation and meaning construction during the reading.

In the same way Womack and Davis (2002) affirm that reader response theory confers attention to the act of reading, and the many different ways in which readers respond to literary texts. In short, meaning is a construction product of the synergistic relationship between the literary text and the reader's subjectivity.
The range of diverse theoretical tenets and foundations of reader-response make this theory a rich complex field, which comprises different approaches to understanding the reader's role in meaning construction during the reading process of a literary text. In this sense, reader-response contends that to fully comprehend a literary text, it is necessary to look into the process that a reader experiences, as well as the relationship between the text and the reader.

Opposing the principles of reader response theory described above, traditionally there have been two approaches in regards to literature teaching and learning; the stylistic and the critical trend. Lazar (1993) explains that stylistic literature analysis aims at fulfilling fixed parameters of both literary genres and historical movements. According to him, stylistic literary analysis tries to account for making meaning from the text. On the other hand, he declares that literary criticism deals with the study of the writer's point of view, mood and text organization.

These two trends do not acknowledge the role of the reader, and the relation between the text and the reader is not considered. The reader is viewed as a passive subject whose feelings, ideas, thoughts and emotions are not taken into account in the act of reading and in the process of meaning construction and interpretation. The reader's role is to extract meaning from the text and analyze its structure based on fixed criteria.

Unlike these two approaches to literature study, Rosenblatt (1995) considers that meaning is not in the text itself, nor in the reader's mind, but in the continuous recurrent mix of the contributions of both. In other words, for this author the literary text comes to life as a result of the selective attention of the reader during the transaction with the text. From this point of view, the reader is seen as an active agent whose whole being is actively involved in the process of reading. Even more, his participation is fundamental in order to make the literary text to come to life.

Regarding the impact of a stylistic and critical approach to literature in the classroom, Sanchez, et 
al. (2004) maintain that this approach to literature explains to a great extent the feeling of frustration and helplessness, of many students and teachers of literature, as well as the rejection of literature as a source for language learning. In the same sense, Rosenblatt argues that literary criticism's terminology obscures the value and richness of the reading process. She posits that literary analysis and criticism have placed reading as an act in which the text impresses its meaning on the reader's mind, and the reader is seen as an agent, passively extracting the meaning embedded in the text.

Conversely, regarding the relation of the reader and literature Lazar (1993) affirms that by their very nature; literary texts give access to the worlds of personal experience which every student carries within. In the same sense, Rosenblatt (1995) proposes an approach to literature as a way to get closer and explore the human spirit and nature. She defends reading literature as a way of living others' emotions, lives and at the same time as a way of getting close to our own emotions, as well as facing vital personal dilemmas. The author adds that the analysis and criticism of the text hinder this kind of connection and relation between the reader and the literary text.

Likewise, Sanchez, et al (2004) state that in middle school the study of literature history with a merely informative character did not make any sense because it was a knowledge that did not mean much to the students, and did not contribute at all with students moral and personal growth. They recommend allowing students to express their personal opinions and responses instead of fostering the repetition of the analysis and arguments of others ideas that do not make much sense to the reader. These authors' assertions advocate for a reader-response based approach to literature which recognizes the active role of the reader and its value to connect students' life experiences to reflection and critical comprehension of moral and ethical issues that are meaningful for the students.

The pedagogical implications of a readerresponse or a stylistic and critical approach to literature for language learning differ in many aspects. An emphasis on a stylistic and critical approach implies that most of the time class activities are about reading comprehension and text structure analysis. Whereas, reader-response based approaches emphasis on the dynamics around the act of reading, and the connections' students make with the text, as well as on their personal reactions and interpretations of the readings.

In a reader-response centered classroom reflection plays a very important role. This element is like the glue that joins literary texts with students' ideas, life experiences and real life events. In other words, reflection facilitates reading transaction between the literary text and the reader; it makes the reading process meaningful because it allows the reader to connect the text with his subjectivity. When this happens, students' motivation increases and language activities become more appealing and meaningful since they have to do with what they think and what they are willing to express.

The role of language is central in a permanent dialogue and reflection, and since the target topics of reflection and dialogue are personal experiences, everyday problems and in general life experiences, the discourse of the classroom becomes something meaningful and the center of interest. Dewey (1900) asserts that children are born language-users, and that they are willing to talk about the things that happen to them, as well as about what interests them. He stated that:

When language is used simply for the repetition of lessons, it is not surprising that one of the chief difficulties of school work has come to be instruction in the mother-tongue. Since the language taught is unnatural, not growing out of the real desire to communicate vital impressions and convictions, the freedom of children in its use gradually disappears (pp. 55-56).

Whereas when classroom activities are disconnected from personal interests and life experiences, the 
primary motivation of human communication is lost, any speaking or writing activity does not seem to have a purpose. Dewey's assertions are supported by the findings of Rojas (2005), who in a qualitative action research case study carried out in a public school in Bogotá with a group of 40 students from seventh grade. The researcher explored how critical activities guided students towards critical literacy. The findings that emerged from the evaluation and interpretation of the data (field notes, audio recordings, and writing samples) evidenced that students expressed their concerns about problems that had to do with them in a direct way; and that they attempted to reflect on social issues that were present in their social and cultural environment.

Another study that examines the importance of connecting language with the social context and real life events was carried out by Niño (2004). This qualitative research case study explored the role of critical thinking in the development of thematic units in nine students from eighth grade in a private school in Bogotá, during one semester. The analysis of the collected data by means of field notes, audio recordings, and students' samples showed that when language educators put language into context, the learning experiences became meaningful for the students.

The standpoints mentioned above, and the findings of the studies, point to the use of language in order to communicate what a person thinks, as well as to reflect about his life experiences, and the happenings that have something to do with the person's life. The presence of these elements drive motivation, and makes language use something appealing and meaningful in language learning. Furthermore, the connection between reader's life experience, his subjectivity and literature is powerful since literature deals with human nature and life itself. This last element is of paramount importance for education because it promotes reflection on issues that help the individual's growth.

The ideas and theoretical stand points mention above implied that learners are viewed as active agents whose subjectivity, life experiences, feelings, knowledge and cultural background are acknowledged in EFL literature-based teaching and learning activities.

\section{Methodology}

The main purpose of the study was to look into a literature-based EFL process in order to understand the underlying dynamics, and practices that drive this kind of language learning program. This matches the characteristics of a qualitative research. Freeman and Long (1991) claim that qualitative research aim is to observe and comprehend what is present rather than to test hypothesis.

Due to the particular features that characterized the population and the setting the study matches the distinguishing features of a case study (Cohen and Marion, 1995).

The population consisted of three groups from seventh grade. Students have been in a literaturebased program since preschool. The school was founded in 1946. Its mission is to educate Christian gentlemen, competent honest professionals, citizens and national leaders, conscious of their social obligations and responsibilities. The core of the school's educational philosophy is the pedagogy of affection and trust.

Data was gathered by means of audio recordings, students' written logs and teachers' journal. These instruments permitted to register information about behaviours, responses and interactions prompted or related to literary texts.

The needs analysis study showed that a better understanding of literature-based EFL learning and teaching was needed in order to improve classroom dynamics that facilitated target language acquisition on the part of the school students. Another result of the needs analysis was that the school needed information about the current English syllabus in order to make informed decisions regarding the school English program. The literature review about literature and language learning provided the 
theoretical elements that oriented the designing of the pedagogical intervention.

The classroom activities aimed at covering three readings of the study plan in three different stages: pre-reading, while reading and post reading. In each of these stages different strategies, and in class activities were adjusted to allow students to tackle the literary selection taking into account the principles of reader response theory, so that they could make personal and meaningful interpretations, and connections with the literary texts.

The first story is Mowgli's Brothers by Rudyard Kipling. This story is about a little baby who is abandoned in the jungle by his parents because they had to run away. A pack of wolves found him and decided to adopt him and raised him.

The Lawyer and the Ghost by Charles Dickens is the second story. In this story a lawyer moves into a gloomy set of rooms. These rooms happened to be haunted by a ghost who died in these very rooms. The lawyer remains calm and convinces the ghost that living in this place is against the ghost's own interest and the ghost disappears.

The third story is The Wounded Wolf by Jean Craighead. In this story a wolf got injured by a caribou when he was protecting another wolf. He is left behind. While being alone, he is attacked by ravens and a fox, but despite the fact that he is hurt he fights them off. He is finally helped by his pack. He recovers and comes back with the pack.

\section{Findings}

\section{Acknowledging the voices of the EFL lear- ners}

Several constructs emerge from the data analysis. These concepts comprise the students' voices, comments, ideas, and personal reactions about the literary texts, and/or topics related to them. These constructs evidence the importance of real life events; the active role of the student and socio-cultural issues in a literature-based EFL process.
The first construct is the materialization of the connections that students make between the literary texts and real life happenings either historical, or events that are currently taking place. The nature of these events is diverse; some events are related to politics, social life, and the specific experiences of people. In the excerpt below, the student relates a real life event that is often reported by mass media with the story Mowgli's Brothers. In this story a human baby is adopted by a pack of wolves when he was left behind by his parents because they had to run away.

When the Farc take to force the people so they have to escape to another sides, poor and indefence, like when Mowgly escape from the tiger and parents were obliged to run away.

(Excerpt taken from the response to literature paper page 61)

In this example the student relates a particular event of the story to real life events that have taken place as consequence of the confrontation between the guerrilla and the government. The student associates the part of the story when the parents of Mowgli, a story's character, were forced to run away leaving him behind with the displaced people because in both cases people have had to run away to save their lives. Moreover, he emphasizes that displayed people, and the characters in the story are helpless and poor when they are forced to flee. Lazar (2008) states that the reader's experiences and knowledge have a great deal to do about the way a reader interpret a text. The student's interpretation of what the characters in the story live and experience when they have to run away seems to be an understanding the student arrives at aided by the knowledge of what happens to displaced people in real life. Likewise; Aebersold and Field (1997) claim that reading in a second language is a dynamic and interactive process. This is evident in this example in which the student connects his knowledge with the reading; and in doing so, he ponders about what happen to displace people and how they feel. 
Furthermore, the connections and relations that students make between the stories and real life events are personal and meaningful. In this active process students attempt to make sense of complex real life happenings by comparing and contrasting them with literary texts' events, characters and themes. As a result, the real world and the classroom are connected. This connection ensures that the topics and learning dynamics become meaningful and relevant.

Another aspect that becomes visible is that EFL learners also recall experiences in which they are directly involved. In the following example astudent describes his personal experience when he was a baby. He relates this event to the story "The wounded wolf"; in this story a hurt wolf survives, thanks to the help he receives from the rest of the pack.

When I was a baby I was verry sick because I was premature of six months. I neded to stay on a hospital all day, and I could not stay with my mom until I was one month old. But with help of my parents I could survive and I grow up. My family diden't give up and diden't rest until, I was completely healthy and I finally could go home

(Excerpt taken from the response to literature paper page 9)

In the explanation that this student gives about the relation that he makes between the story and his real life experience he says:

The relation between my real life experience and the story is that as the pack diden't abandon Roko, when he was wounded and need help, my family also diden't abandon me when I was sick and I could no survive by myself. My family is like Roko's pack

(Excerpt taken from the response to literature paper page 9)

In the explanation the student gives, he establishes that he and one of the characters of the story had been very sick and that both of them had survived thanks to the help they had received from others. In the last statement he compares his family to the pack of wolves because his family had helped him when he was sick, just as the pack of wolves with the wolf which had been in a similar situation to him. It is clear that the student evokes what he lived and felt. This recollection gives him the chance of pondering what he lived by comparing his experience with the event in the text. This reflection led him to value what his family had done for him.

These kinds of associations encourage students to reflect on their personal experiences from different and fresh perspectives. This helps them to objectively understand and enrich the comprehension of their life experiences, feelings and emotions. In this sense, Lazar (2008) sustains that the use of literature enables students to understand human emotions, feelings as well as why the members of a society behave in certain way. Furthermore, the fact that students bring up these kinds of issues in an EFL classroom provides a springboard that might be used to tackle topics that are meaningful and relevant for students and thus making EFL language learning classroom activities more student-centered.

The third construct comprises the students ideas and thoughts about what is right or wrong, bad or good and the messages or lessons conveyed in the reading, or the ones that the learners draw from the reflections they make about their life experiences or real life events. Students think about the characters' actions, stories events, themes, real life events and personal experiences, and take a position on these. They assume a critical stance and give some arguments that support their ideas and thoughts. In this process they compare and contrast characters' actions and stories events with personal life experiences and real life events. Students also associate people's feelings, emotions and behavior with those of the characters in order to evaluate and give their opinion about characters' behaviors, attitudes and acts. In the example below the student expresses an opinion in 
which he determines that the behavior of one of the story's character was appropriate.

The mom wolf is a good mom that work to his babies were good in the jungle in all aspects

(Excerpt taken from the response to literature papers page 24)

In this example the student expresses a value judgment about the behavior of one of the characters of the story, the mother wolf. He recognizes that this character has observed a particular behavior and that due to this; this character is a good mother wolf. The student takes a position about the character's behavior. He analyzes the characters' actions, and based on his own experience he comes to the conclusion that the character is a good mother wolf. The analysis that the student does and the conclusion he arrives at evidences that he is not just retrieving information from the text, but that he is actively analyzing and reflecting. In this sense Lazar (2008) states that literature might engage students in the analysis of human feelings, emotions and behavior. Lazar says that this might be very absorbing for students and that this might raise students' motivation. In the case of the student, what he read in the story elicited an emotional response from him. The fact that the student has done this kind of analysis on this particular subject becomes relevant taking into account that the student is a teenager. It is relevant that he does this kind of analysis at an age when people are mostly concerned about making sense of themselves and the world where they live in. Furthermore, the student does this interpretation and expresses his ideas on this particular issue because he had the freedom to express what he thought. In this respect, Lazar (2008) states that when students are given the chance to freely respond to a literary text, they respond personally and become more confident about expressing their ideas in English. The student above and the one in the following example seem to feel empowered and able to express their ideas. This is evident because they interpret the text from their point of view as well as communicate their ideas about a topic that they rarely have the chance to talk about in their daily lives. These elements are also present in the following excerpt.

In the following excerpt taken from the transcriptions of the small group discussions, the student expresses his idea in relation to the message or moral of the story "Mowgli's brothers". In this story a human baby is abandoned by his parents because they have to run away and he is adopted by a pack of wolves.

- Student 1: well eh...(::.) the jungle book, the jungle book eh...it was very funny (:::) first of all I think that the theme of the story is like everyone is a special way depends on others, eh for example I depend from my parents because they give me... they give me popular things eh... the things like (::) so, eh... also the teachers we depend on them because they decided what we work or not, eh if what we are saying is true, or if what we are saying is not true. So I think that the theme basically is that, that everyone depends from another thing or person.

- Teacher: asks about how that theme is revealed through the story.

- Student 1: Eh, for example when father Rocko and the mother found the human cub, Mougli, eh...Mougli was baby so he eh...can't like take care of, of himself. So... so father wolf and other wolf because they are parents they decide to... to take care of the... of the... of Mougli and protect him from Sheerkan, eh... help him eh when the, when the council decided to...to...to.. that Mougli would be a part of the pack. I think that the parts (:::)

- Teacher: asks the student if he relate the story with something else.

- Student 1: uhmm maybe with... how do you say liderazgo?

- Teacher: leadership.

- Student 1: Maybe with leadership because eh the pack have a leadership, the family of the wolves have a leadership, 
Sheerkan is a leadership.

- Teacher: it's a leader.

- Student 1: yes, eh, so I think that the leadership is another (:::) personality of the characters and the story.

(Taken from small group transcriptions, recording number $6,2008 / 11 / 29$ )

In the passage above, the student states that the theme or message of the story is that; everyone depends on others. He supports his statement explaining that he depends on his parents because they give him what he needs; in addition, he states that students depend on teachers because they tell students what to work on as well as tell when they are wrong or right. Furthermore, the student explains how the story reveals that message. He makes clear that in the story the human baby depended on the pack of wolves and that he would have not survived otherwise. It is significant that the student acknowledges how important his parents and teachers are for him and that he values in some way what they have done for him. It is also significant the fact that this reflection has been provoked by an aspect of the literary selection that the student read.

The two students in these excerpts made assertions that contain fresh elements that they had probably not thought of before they read the literary texts, and before having the chance to freely express themselves about these topics. This suggests that students reflect upon real life people's behaviors, acts, feelings, and personal life events when they read, compare and relate these elements with what happens in literary texts. With regard to this, Lazar (2008) asserts that literature is useful for encouraging students to draw on their own personal experiences, feelings and opinions. In the examples, students gain some insights into their own ideas and most inner beliefs and established and inner reflection and dialogue that they managed to voice despite of the effort they have to make to articulate their ideas having low language proficiency. Furthermore, in doing this, students engaged in an activity that implies not only using the target language or drilling on language patterns, but also using thinking skills, assuming critical and reflective stances about valuable topics for students.

The fourth construct has to do with the meaningful use of the target language in EFL. This element emerges throughout the different activities in which students participated. Interest, eagerness and motivation characterized students' participation and interventions. Their willingness to use the target language in order to take part in activities is particularly relevant. This was evident because students' interventions and comments were spontaneous and show a genuine purpose in communicating something important for them. Students really want to share with others despite the efforts involve in expressing themselves in the target language. The excerpt below was written in the teacher's journal and corresponds to one session in which students talk and discuss about stories or experiences regarding ghosts. This occurred in an activity that carried out before reading the story the Lawyer and the Ghost

Students who told their experiences
and comments during the activity were
motivated; they showed great interest, they
really wanted to share their experiences
with the rest of the class. Some students
could not participate because there was
not enough time. Once the class was over,
I heard some of these students talking
about their experiences and stories.
Students that spoke made a great effort
to get their ideas across, for some of them
this was a very demanding task because
their language command is limited.

(Excerpt taken from the teacher's journal page 1, 2008/10/22.)

In the teacher's journal entry above, are motivated and willing to express themselves in the target language because they have something meaningful and relevant to express. These elements infuse the language use 
with a purpose that goes beyond the mere practice of the language. This purpose seems to be more individual and prompted by students' personal life experiences.

Another example that illustrates this category is taken from the transcriptions of the small group discussions. In the transcription passage below, student 1 jumped in with a comment about something that his father had told him.

- Teacher: asks if he had been in the farm?

- Student 2: yes, at night... sometimes it is like scare like eh..it's scare because my cousins begin to do like movements and sounds, sometimes I...

- Students 1: Drops in (::::) when I, ... my father told me that when I was young... in my (:::) I saw a ghost in a... in a (como se dice cancha)

- Teacher: soccer field or..

- Student 1: a field of squash

- Teacher: ok. A squash court

- Student 1: eh... eh he told me that the one that it was in charge of the squash eh..

- Teacher: court

- Student 1: court it was impressed because the last day a..a man died because of a....

- Teacher: a heart attack?

- Student 1: a hear t attack.

(Taken from the transcriptions of the small group discussions, recording 1 , 2008/10/25)

In this example, Student 1 interrupted Student 2 because he wanted to tell what his father had told him about a man that had died in a squash court. Student 1 fumbled for words and the teacher helped him several times. He made a great effort to communicate his ideas. It is also significant that he jumped in spontaneously and that he had already taken part in the discussion before. These facts are evidences of his enthusiasm to express his ideas motivated by a genuine desire of communicating his experience despite of his lack of language command, and the effort that implied to try to articulate his ideas.

In the two examples above students' eagerness to express something meaningful is the motivation that drives them to take the risk and make the effort to articulate their thoughts. The use of the language in these activities is clearly meaningful, and the students' subjectivity is involved. These elements drive motivation due to there is a purpose for language use that goes beyond the mere use of the language. This enhances language use and therefore language acquisition. In this regard Lazar (2008) argues that focusing on activities in which students openly express their responses on any aspects prompted by a literary text can only serve to accelerate the learner's acquisition of language.

Another element that emerges by analyzing the excerpts above is the implicit relation between the reader and the text. The fact that students connect specific events and aspects of the texts with particular life experiences and real life events evidences the synergistic relation between the reader and the text during the reading process.

The above constructs; product of the analysis and interpretation of EFL learners responses and connections to literary texts, underscores the value and roles of literature in FL learning. The voices of students also hint to some teaching and learning practices driven by literature which worth continuing pondering about in pursuing more informed, meaningful, and rich FL educational programs and practices. The conclusion below lay out some of these issues.

\section{Conclusions}

The connections students make between literary texts and people's behavior, attitudes, feelings, and 
emotions encourage students to reflect and analyze about these human issues. This makes possible a better comprehension of students' own subjectivity as well as the other's.

Students' personal experiences and sociocultural background have a very important role in literature-based EFL learning and teaching. When these elements are brought up in the classroom, students' motivation increases; learners are entirely involved, and they openly express their opinions, reactions, ideas and feelings. This makes the use of the target language more meaningful and appealing in the classroom.

The associations and connections students make to literary texts engage learners in a reflective activity in which students assume critical stances that encourage the development of thinking skills like: comparing, contrasting, making inferences, describing, supporting ideas, providing evidences and arguments. This promotes language use, interactions and discussions in which the voices of the individuals are heard, value and confronted making possible a dialectic environment in which the individuals' conceptions, ideas, beliefs, and notions are permanently being revised, enriched and changed. This makes FL learning a source of empowerment and personal growth for the language learner.

\section{Pedagogical implications}

Literature-based EFL programs ought to acknowledge and integrate in the teaching and learning practices issues regarding learners' sociocultural background, previous knowledge, life experiences, and real life events. These elements help students to connect real life to literary texts. Therefore, students have valuable elements, and points of view that allow them to gain a better understanding of both; real life and literary texts.

Literature in EFL should be used as a source that provides meaningful topics and issues of exploration, discussion, analysis and reflection. Language learning activities are articulated around these topics and issues; this implies that the target language becomes the means in the process not the object of study, nor the ultimate goal in the process.

The use of literature in EFL requires a particular methodology and didactics that allow the language learners to get access to the literary texts' content, structure and meanings. This demands from the EFL teacher a shift in his conception of what learning and teaching a FL implies; his strategies, and knowledge of the relation of literature; language learning and education.

\section{References}

Booth, W. (1961). The rhetoric of fiction. Chicago: Chicago university press.

Cohen, L. \& Manion, L. (1995). Research methods is education. London and New York: Routledge Taylor and Francis group.

Dewey, J. (1900). The school and society. Chicago: University press.

Freeman, L. \& Long, D (1991). An introduction to second language acquisition research. New York: Longman.

Gibson, J. (1950). The Perception of the Visual World. Ogdensburg, NY, U.S.A: Houghton Mifflin

Hopkins, D. (1995). A teachers guide to classroom research. Buckingham, Philadelphia: Open University Press

Hubbard, R. \& Miller, B. (1993). The art of classroom inquiry: A handbook for teacher researchers. New Hampshire: Heinemann.

Lazar, G. (1993). Literature and Language Teaching: A guide for teachers and trainers. Cambridge: Cambridge University Press.

Lazar, G. (2008). Literature and Language Teaching: A guide for teachers and trainers (16th Ed.). Cambridge: Cambridge University Press.

Miller, M. \& Hubbard, R. (1991). The Heinemann reader literacy in process: N.H. Heinemann: Portsmouth.

Niño, A. (2004). The role of critical thinking in the development of thematic units in an EFL context. (Thesis). Bogotá: Universidad Distrital Francisco José de Caldas. 
Richards, I. (1929). Practical criticism-A study of literary judgment. A harvest book. San Diego New YorkLondon.

Rojas, R. (2005). Guiding students through a pedagogy that promotes critical literacy (Thesis). Bogotá: Universidad Distrital Francisco Jose de Caldas.

Rosenblatt, L. (1978). The Reader, the Text, the Poem: The transactional Theory of the Literary Work. Carbondale: Southern Illinois University Press.

Rosenblatt, L. (1991). Literary Theory. In J. Flood et al. (eds.) Handbook of Research on Teaching the English Language Arts (pp. 57-62). Mahwah, NJ:
Lawrence Erlbaum Associates.

Rosenblatt, L. (1995). Literature as exploration New York: the modern language association.

Sánchez, J. \& Rincón, E. F. (2004). Enseñar literatura / certezas e incertidumbres para un cambio: México: Editorial Laia, S.A.

Tompkins, J. (Ed.). (1980). Reader-response criticism. Baltimore: John Hopkins University Press.

Womack, K. \& Davis, F. (2002). Formalist criticism and reader-response theory. New York: Basingstoke, Hampshire.

THE AUTHOR

LUIS JESÚS RINCÓN USSA is a full-time professor and researcher at La Salle University. His research interests include curriculum management and design, applications of ICT in language learning and literature in EFL. He holds an M.Ed. in Applied Linguistics to teaching English from Universidad Francisco José de Caldas, and a B.A. degree in Modern Languages from Universidad de La Salle. His professional experience includes, fifteen years teaching English in high school and university levels, pedagogical practicum supervisor, and director of undergraduate research theses. 